\title{
Processes and environmental quality in the Yangtze River system
}

\author{
H. Hollert
}

Received: 22 February 2013 / Accepted: 14 June 2013 /Published online: 11 July 2013

(C) Springer-Verlag Berlin Heidelberg 2013

The Yangtze River is a source of life and prosperity for China and the river basin is home to 400 million people, one third of the population of China. The river basin accounts for approximately $50 \%$ of the national total runoff and $40 \%$ of China's freshwater resources, which makes the river basin the most important source for drinking water, supplying water to 186 cities. In addition, it is one of the major arteries of China's inland water transportation. The fish fauna of the Yangtze catchment is one of the richest in the world, providing more than $70 \%$ of the fishery production of China. Due to its rich natural resources, the river contributes a lot to China's economic development. It serves as a key factor in inter-provincial commercial trade and the regional economy. The potential benefits even grew after the Three Gorges Dam began operating at full capacity after 2009, including flood control, energy production, and improved navigation. The river is also among the key locations for China's agriculture and industry. In 2006, the river hosted 10,000 chemical enterprises - about half of the total number in China (cf., Floehr et al. 2013, this issue).

However, the Yangtze River - as an ecosystem as well as a lifeline - is reported to have been drastically degraded during recent decades (Muller et al. 2008; Xie 2003). A recently published focus story in Science entitled "Trouble on the Yangtze" highlights the potentially serious consequences of proposed and completed hydropower dams on the Yangtze River for fish and cetaceans (Qiu 2012). As pointed out by

Responsible editor: Philippe Garrigues

H. Hollert $(\bowtie)$

Institute for Environmental Research (Biology V),

Department of Ecosystem Analysis, RWTH Aachen University,

Worringerweg 1, 52074 Aachen, Germany

e-mail: henner.hollert@bio5.rwth-aachen.de

H. Hollert

College of Resources and Environmental Science, Chongqing

University, Chongqing 400030, People's Republic of China
Yang et al. (2012) in a reply to the above-mentioned article, water pollution is another important but largely ignored concern; rising contamination and hydrological changes in the Yangtze River accelerate the loss of local species.

Discharge of industrial and urban wastewaters, along with the application of fertilizers, pesticides, and herbicides in farming, have negative impacts on the water quality (Muller et al. 2008; Yang et al. 2012; Jin et al. 2012). These impacts include release of heavy metals and persistent organic pollutants as PAHs, together with re-mobilization of polluted sediments. Due to its pollution, the Yangtze River was rated by the World Wildlife Fund as being amongst the top 10 rivers at risk in the world (Wong et al. 2007; Wang et al. 2012a).

This special issue of Environmental Science and Pollution Research highlights selected papers presented at two International Workshops on "Processes in the Yangtze River System-Experiences and Perspectives", one held at RWTH Aachen University, Germany in 2011, and the other at Tongji University in Shanghai, China in 2012. Both workshops were held for the purpose of scientific exchange on recent cuttingedge environmental research in the Yangtze River with a focus on the Three Gorges Reservoir (TGR). The second of these conferences, which is summarized in a conference report by Holbach et al. (2012a), marked two important milestones in Sino-German cooperation: (a) the 10-year anniversary of successful scientific Sino-German cooperation on questions related to the newly built Three Gorges Dam and (b) the midpoint of the Yangtze-Hydro Project (Bergmann et al. 2012) funded by the German Federal Ministry of Education and Research from 2010 to 2014.

In detail, more than a dozen papers on processes and environmental quality in the Yangtze River basin are presented in this special issue elucidating the following topics:

- Modeling the biomagnification of organic pollutants in aquatic food webs (Scholz-Starke et al. 2013)

- Review on the toxicological status (Floehr et al. 2013)

- Contamination status of dioxins in sediment cores from the Three Gorges Dam area (Chen et al. 2013) 
- Application of $15 \mathrm{~N}-18 \mathrm{O}$ double stable isotope tracer technique (Liang et al. 2012)

- Mitigation of nutrient losses via surface runoff from rice cropping systems with alternate wetting and drying irrigation

- Case study on rehabilitation of a polluted urban water body

- Water mass interaction in the confluence zone of the Daning River and the Yangtze River in respect to algal growth (Holbach et al. 2012b)

- Approximation and spatial regionalization of rainfall erosivity based on sparse data (Schönbrodt-Stitt et al. 2013)

- Temporal variation and spatial distribution of PAH (Wang et al. 2012b)

- The littoral zone in the Three Gorges Reservoir: challenges and opportunities (Yuan et al. 2013)

- The response of mulberry trees after seedling hardening to summer drought in the hydro-fluctuation belt (Huang et al. 2012)

- Chemical and effect oriented exposomics: Three Gorges Reservoir (Schramm et al. 2012)

- Dechlorination and organohalide-respiring bacteria dynamics in sediment samples (Kranzioch et al. 2013)

- Plant communities in relation to flooding and soil characteristics in the water level fluctuation zone (Ye et al. 2012)

In order to provide a comprehensive picture of processes in the water fluctuation zone of the TGR, where the water level fluctuates annually by about $30 \mathrm{~m}$ generating a drawdown zone of up to $350 \mathrm{~km}^{2}$ in summer (Yuan et al. 2013), and the concept of optimizing ecosystem services in this area according to the strategy presented by Mitsch et al. (2008), Willison et al. (2013) present the major outcomes of an international conference held in Chongqing Municipality (China) in October 2011 on the subject of conservation and eco-friendly utilization of wetlands in the Three Gorges Reservoir. The bilingual (English and Chinese) conference proceedings were subsequently published (open access) in the Journal of Chongqing Normal University. The proceedings reports are critically reviewed by Willison et al. (2013) in this special issue of ESPR in the context of other internationally relevant literature.

The increasing worldwide contamination of freshwater systems with thousands of industrial and natural chemical compounds is one of the key environmental problems of the twentyfirst century (Schwarzenbach et al. 2006; Yang et al. 2012) and global challenges. Considering this alarming situation, which were addressed in the mentioned Yangtze cooperation projects and workshops, the following lessons can be learned:

(a) to understand the complex environment of the Three Gorges Reservoir and to develop research strategies a long standing and sustainable cooperation is needed; (b) basic research is needed for the development of conceptual strategies and technical solutions considering the multidimensional environmental problems in this region;

(c) joint forces supported by bi- and multilateral, international research programs are needed;

(d) research programs to support fundamental research are often too short-lived to derive reliable results and sustainable solutions.

(e) For this reason, it is necessary that basic and applied research sponsors combine their forces and to create specific calls in the funding bodies that address basic and applied research in environmental sciences (Schaeffer et al. 2009).

Acknowledgments The author would like to thank the Federal Ministry of Education and Research, Germany (BMBF) for supporting the research cluster "Pollutants/Water/Sediment-Impacts of Transformation and Transportation Processes on the Yangtze Water Quality" and the BMBF DLR for supporting a cooperation project with Chinese colleagues. The author would also like to thank Prof. Dr. Martin Willison (Dalhousie University, Canada) for improving the language of this editorial.

\section{References}

Bergmann A, Bi Y, Chen L, Floehr T, Henkelmann B, Holbach A, Hollert H, Hu W, Kranzioch I, Klumpp E, Kuppers S, Norra S, Ottermanns R, Pfister G, Ross-Nickoll M, Schaffer A, Schleicher N, Schmidt B, Scholz-Starke B, Schramm KW, Subklew G, Tiehm A, Temoka C, Wang J, Westrich B, Wilken RD, Wolf A, Xiang X, Yuan Y (2012) The Yangtze-Hydro Project: a Chinese-German environmental program. Environ Sci Pollut Res 19:1341-1344

Chen L, Bi Y, Zhu K, Hu Z, Zhao W, Henkelmann B, Bernhöft S, Temoka C, Schramm K-W (2013) Contamination status of dioxins in sediment cores from the Three Gorges Dam area, China. Environ Sci Pollut Res. doi:10.1007/s11356-11012-11447-11352

Floehr T, Xiao H, Scholz-Starke B, L1 W, Hou J, Yin D, Zhang X, Ji R, Yuan X, Ross-Nickoll M, Schäffer A, Hollert H (2013) Solution by dilution?-A review on the pollution status of the Yangtze River. Environ Sci Pollut Res. doi:10.1007/s11356-013-1666-1

Holbach A, Floehr T, Kranzioch I, Wolf A (2012a) Dilution of pollution? Processes affecting the water quality in the river-style Three Gorges Reservoir. Environ Sci Pollut Res. doi:10.1007/s11356012-1252-y

Holbach A, Wang L, Chen H, Hu W, Schleicher N, Zheng B, Norra S (2012b) Water mass interaction in the confluence zone of the Daning River and the Yangtze River - a driving force for algal growth in the Three Gorges Reservoir. Environ Sci Pollut Res. doi:10.1007/s11356-11012-11373-11353

Huang X, Liu Y, Li J, Xiong X, Chen Y, Yin X, Feng D (2012) The response of mulberry trees after seedling hardening to summer drought in the hydro-fluctuation belt of Three Gorges Reservoir Areas. Environ Sci Pollut Res. doi:10.1007/s1135611012-11395-x

Jin XW, Gao JJ, Zha JM, Xu YP, Wang ZJ, Giesy J, Richardson K (2012) A tiered ecological risk assessment of three chlorophenols in Chinese surface waters. Environ Sci Pollut Res 19:1544-1554 
Kranzioch I, Stoll C, Holbach A, Chen H, Wang L, Zheng B, Norra S, Bi Y, Schramm K-W, Tiehm A (2013) Dechlorination and organohalide-respiring bacteria dynamics in sediment samples of the Yangtze Three Gorges Reservoir. Environ Sci Pollut Res. doi:10.1007/s11356-11013-11545-11359

Liang XQ, Nie ZY, He MM, Guo R, Zhu CY, Chen YX, Küppers S (2012) Application of $15 \mathrm{~N}-18 \mathrm{O}$ double stable isotope tracer technique in an agricultural nonpoint polluted river of the Yangtze Delta Region. Environ Sci Pollut Res. doi:10.1007/s11356-11012-11352-11358

Mitsch WJ, Lu JJ, Yuan XZ, He WS, Zhang L (2008) Optimizing ecosystem services in China. Science 322:528-528

Muller B, Berg M, Yao ZP, Zhang XF, Wang D, Pfluger A (2008) How polluted is the Yangtze river? Water quality downstream from the Three Gorges Dam. Sci Total Environ 402:232-247

Qiu JN (2012) Trouble on The Yangtze. Science 336:288-291

Schaeffer A, Hollert H, Ratte HT, Ross-Nickoll M, Filser J, Matthies M, Oehlmann J, Scheringer M, Schulz R, Seitz A (2009) An indispensable asset at risk: merits and needs of chemicals-related environmental sciences. Environ Sci Pollut Res 16(4):410-413

Scholz-Starke B, Ottermanns R, Rings U, Floehr T, Hollert H, Hou J, Li $\mathrm{B}, \mathrm{Wu} \mathrm{L}$, Yuan X, Strauch $\mathrm{K}$, Wei H, Norra S, Holbach A, Westrich B, Schäffer A, Roß-Nickoll M (2013) An integrated approach to model the biomagnification of organic pollutants in aquatic food webs of the Yangtze Three Gorges Reservoir ecosystem using adapted pollution scenarios. Environ Sci Pollut Res. doi:10.1007/s11356-11013-11504-11355

Schönbrodt-Stitt S, Bosch A, Behrens T, Hartmann H, Shi X, Scholten $\mathrm{T}$ (2013) Approximation and spatial regionalization of rainfall erosivity based on sparse data in a mountainous catchment of the Yangtze River in Central China. Environ Sci Pollut Res. doi:10.1007/ s11356-11012-11441-11358

Schramm K-W, Wang J, Bi Y, Temoka C, Pfister G, Henkelmann B, Scherb H (2012) Chemical- and effect-oriented exposomics: Three Gorges Reservoir (TGR). Environ Sci Pollut Res. doi:10.1007/ s11356-11012-11319-

Schwarzenbach RP, Escher BI, Fenner K, Hofstetter TB, Johnson CA, von Gunten U, Wehrli B (2006) The challenge of micropollutants in aquatic systems. Science 313:1072-1077

Wang Y, Li X, Li BHH, Shen ZYY, Feng CHH, Chen YXX (2012a) Characterization, sources, and potential risk assessment of PAHs in surface sediments from nearshore and farther shore zones of the Yangtze estuary, China. Environ Sci Pollut Res 19:4148-4158

Wang J, Henkelmann B, Bi Y, Zhu K, Pfister G, Hu W, Temoka C, Westrich B, Schramm K-W (2012b) Temporal variation and spatial distribution of PAH in water of Three Gorges Reservoir during the complete impoundment period. Environ Sci Pollut Res. doi:10.1007/ s11356-11012-11427-11356

Willison JHM, Li R, Yuan X (2013) Conservation and ecofriendly utilization of wetlands associated with the Three Gorges Reservoir. Environ Sci Pollut Res. doi:10.1007/s11356-012-1438-3
Xie P (2003) Three-Gorges Dam: risk to ancient fish. Science 302: $1149-1149$

Yang H, Xie P, Ni LY, Flower RJ (2012) Pollution in the Yangtze. Science 337:410-410

Ye C, Zhang K, Deng Q, Zhang Q (2012) Plant communities in relation to flooding and soil characteristics in the water level fluctuation zone of the Three Gorges Reservoir, China. Environ Sci Pollut Res 20(3):1794-1802. doi:10.1007/s11356-11012-11148-x

Yuan X-z, Zhang Y-w, Liu H, Xiong S, Li B, Deng W (2013) The littoral zone in the Three Gorges Reservoir, China: challenges and opportunities. Environ Sci Pollut Res. doi:10.1007/s11356-1101211404-11350

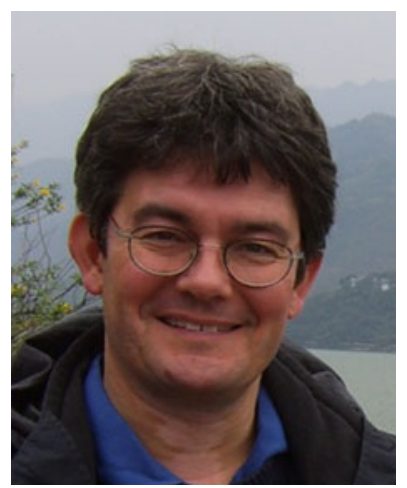

Henner Hollert is professor and one of the two heads of the Institute of Environmental Research, RWTH Aachen University, Germany and adjunct professor at the University of Chongqing in China. He is expert in bioanalytical environmental toxicology, aquatic toxicology, development and validation of in vitro bioassays, sediment and soil toxicology, wasteand ground water investigations, effect-directed analysis, and weight-of-evidence approaches. $\mathrm{He}$ is one of the PIs within the German Excellence Cluster Tailor made fuels from biomass at RWTH Aachen University and head of the working group on bioassays in the European Norman Network. In 2012, he was chair of the local organizing committee of the SETAC World Congress in Berlin and one of the organizers of the German-American Frontiers of Science Symposia (US $\mathrm{Na}$ tional Academy of Science and Humboldt Foundation). He is council member of the Society Environmental Toxicology and Chemistry, EuropeGerman Language Branch (president in 2004) and is one of the core group members of BioSC (Bioeconomy Science Centre).

$\mathrm{He}$ is editor in chief of Environmental Sciences Europe, the relaunch of Umweltwissschaften und Schadstoffforschung (UWSF) as the first international Open Access Journal in Environmental Sciences at Springer publishers. Since 2005, he is editor at Environ Sci Poll Res and subject editor of $J$. Soils Sediments. He has published more than 150 peer-reviewed international and national articles as well as book chapters in this area (98 listed in ISI-Web-of-Science).

Together with his colleagues Andreas Schäffer and Martina RoßNickoll, he started in 2010 to investigate the environmental quality of the TGR in China and co-organized several international scientific meetings in Germany and China addressing the environmental processes in the TGR. 